Self-determination, immigration restrictions, and the problem of compatriot deportation
Journal of International Political Theory

I-23

(c) The Author(s) 2014

Reprints and permissions: sagepub.co.uk/journalsPermissions.nav DOI: |0. | |77/| 7550882 |45394| 4 ipt.sagepub.com (\$)AGE

\title{
Javier Hidalgo[AQI]
}

University of Richmond, USA

\begin{abstract}
Several political theorists argue that states have rights to self-determination and these rights justify immigration restrictions. Call this: the self-determination argument for immigration restrictions. In this article, I develop an objection to the selfdetermination argument. I argue that if it is morally permissible for states to restrict immigration because they have rights to self-determination, then it can also be morally permissible for states to deport and denationalize their own citizens. We can either accept that it is permissible for states to deport and denationalize their own citizens or reject the self-determination argument. To avoid this implication, we should reject the self-determination argument. That is, we should also reject the conclusion that rights to self-determination can justify any significant immigration restrictions.
\end{abstract}

\section{Keywords}

Deportation, global justice, immigration, self-determination

\section{Introduction}

Immigration restrictions coercively prohibit people from crossing borders and settling in other states. States use guards, guns, walls, and other barriers to stop the international movement of people. States restrict immigration in part because most people and international law accept that states have rights to control immigration. But why do states have rights to control immigration? The most influential argument for the belief that states have these rights appeals to self-determination. I will refer to this argument as the self-determination argument for immigration restrictions. Michael Walzer influentially articulated this argument. Walzer (1983) claimed, "Admission and exclusion are at the core of communal independence. They suggest the deepest meaning of self-determination" (p. 62). More recently, Christopher Wellman (2008),

Corresponding author: [AQ2]

Javier Hidalgo, University of Richmond, 28 Westhampton Way, Jepson Hall, Richmond, VA 23I73, USA.

Email: hidalgoj@gmail.com 
David Miller (2007), and other authors have appealed to rights to self-determination in order to justify immigration restrictions (Pevnick, 2011).

In this article, I will develop an objection to the self-determination argument. I contend that if it is morally permissible for states to restrict immigration because they have rights to self-determination, then it is also morally permissible for states to deport and denationalize their own citizens. We can either accept that it is permissible for states to deport and denationalize their own citizens or reject the self-determination argument for immigration restrictions. I will argue that we should opt to reject the selfdetermination argument. This article will proceed as follows. I will first clarify the selfdetermination argument. I will then argue that either it is morally permissible for states to restrict immigration and deport their own citizens, or both of these activities are impermissible. Finally, I will argue that we have strong reasons to reject the selfdetermination argument to avoid the implication that it is permissible for states to deport their own citizens. [AQ3]

\section{The self-determination argument}

According to international law, certain groups have rights to self-determination. The International Covenant on Civil and Political Rights claims that "[a]ll peoples have the right of self-determination. By virtue of that right they freely determine their political status and freely pursue their economic, social and cultural development." The African Charter on Human Rights and People's Rights says, "All peoples...shall have the unquestionable and inalienable right to self- determination. They shall freely determine their political status and shall pursue their economic and social development according to the policy they have freely chosen." But the concept of self-determination is obscure. The core idea of self-determination seems to be that certain groups are entitled to control their own affairs. Yet we need to answer some questions to help clarify this idea.

First, who has rights to self-determination? It seems plausible that certain states have these rights. If a state possesses certain properties, then this state qualifies for rights to self-determination. But people disagree about which properties states must possess to qualify for rights to self-determination. Some authors contend that states must be democratic to be self-determining, while other theorists think that nondemocratic states can qualify for rights to self-determination insofar as these states adequately represent the interests or values of their citizens. In addition, it may be that states possess rights to self-determination only in a derivative sense. For instance, it could be that only nations or peoples have rights to self-determination, but states can exercise these rights on behalf of the nations or peoples that they represent. ${ }^{1}$ For purposes of illustration, I will assume that democratic states have rights to selfdetermination, but my arguments will leave open whether other kinds of states or groups can also have these rights. I will refer to states that have the right properties to possess or exercise rights to self-determination as "legitimate states."

At first glance, rights to self-determination are claim-rights against interference. That is, states have rights to self-determination if other states are under duties to refrain from coercively interfering with the domestic affairs of these states. This aspect of selfdetermination is connected with the institution of state sovereignty. Sovereignty is 
commonly thought to protect the rights of legitimate states to freely determine their own affairs by requiring other agents to respect states' territorial integrity. ${ }^{2}$ But selfdetermination might involve more than claim-rights against interference. Selfdetermination might also ground certain liberty-rights. Liberty-rights are moral permissions: agent $\mathrm{A}$ has a liberty-right to phi if $\mathrm{A}$ is morally permitted to phi. According to the self-determination argument for immigration restrictions, if a state has a right to self-determination, then this state also has a liberty-right to restrict immigration. In his seminal discussion of immigration, Michael Walzer (1983) claimed, "Across a considerable range of the decisions that are made, states are simply free to take in strangers (or not)" (p. 61). Walzer is suggesting that states have libertyrights to restrict immigration. This position is also influential outside of academic political philosophy. The United Nations recently released a comprehensive report on the relationship between migration and human development. The report acknowledges that migration has many benefits for people in poor countries, but the authors of the report reject open borders. They reject open borders because "we recognize that people at destination places have a right to shape their societies, and that borders are one way in which people delimit the sphere of their obligations to those whom they see as members of their community" (United Nations Human Development Programme (UNHDP), 2009: 17).

But why might rights to self-determination justify liberty-rights to restrict immigration? The rough idea is that if states have rights to self-determination, then states have moral entitlements to control their affairs. Immigration changes the composition, character, and size of a society by introducing new cultural practices and people who have different beliefs and values than the recipient population. A state has a right to control membership because the distribution of membership has significant implications for citizens' interests in shaping the future character of their society. Christopher Wellman (2008) notes along these lines that because

the members of a group can change, an important part of group self-determination is having control over what the "self" is ... a significant component of group self-determination is having control over the group which in turn gets to be self-determining. (p. 115)

David Miller (2007) similarly defends immigration restrictions by appealing to

the value of self-determination, to the importance to a political community of being able to determine its future shape, including for example the balance it wishes to strike between economic growth and environmental values, and pointing out that questions of membership are intimately involved in such decisions. (p. 223)

However, different philosophers describe and justify states' rights to self-determination in different ways. Wellman argues that rights to self-determination entail rights to freedom of association. If states have rights to freedom of association, then these states have rights to exclude foreigners. Just as voluntary associations have rights to exclude non-members, the citizens of legitimate states also have rights to refuse to associate with potential immigrants. Other authors, such as Walzer and Miller, claim that citizens have rights to self-determination in part because they have interests in controlling the culture of their society. Walzer (1983) argues that communities need to have rights to 
self-determination to maintain and preserve "communities of character"- "historically stable, ongoing associations of men and women with some special commitment to one another and some special sense of their common life" (pp. 61-62). Miller says that people have interests in controlling their public culture. Citizens "want to be able to shape the way that their nation develops, including the values that are contained in the public culture" and that this interest grounds a right to control immigration (Miller, 2005: 200). Other theorists contend that citizens have rights to self-determination because they have ownership rights over their political institutions and that these ownership rights permit citizens to exclude foreigners from these institutions (Pevnick, 2011).

So, there are several different versions of the self-determination argument. But we can sketch a general version of this argument. It goes like this:

1. Legitimate states have rights to self-determination.

2. If a state has a right to self-determination, then this state has a liberty-right to control what the "self" is - that it, this state has a liberty-right to control access to membership.

3. If a state has a right to control access to membership, then this state has a libertyright to restrict immigration.

4. So, legitimate states have liberty-rights to restrict immigration.

I will refer to this general argument as the self-determination argument.

Critics raise different objections to the self-determination argument. Some critics suggest that the self-determination argument faces a "boundary" problem (Abizadeh, 2008). These critics claim that the self-determination argument begs the question in favor of immigration restrictions because this argument assumes that the current distribution of membership rights is justified (Cole and Wellman, 2011). But this is precisely what the argument aims to show. So, the self-determination argument might be circular. I will develop a different objection to the self-determination argument. My objection to the self-determination argument is that the self-determination argument has unacceptable implications. In order to avoid these implications, we must also reject premise 2 of the argument - the premise that states have liberty-rights to control membership. If states lack these rights, then they also not have liberty-rights to restrict immigration.

\section{The asymmetry}

Adherents of the self-determination argument accept:

Restrict. It is morally permissible for legitimate states to restrict immigration in virtue of the fact that these states have rights to self-determination.

States restrict immigration when they enforce border restrictions, such as the construction of fences and the creation of border patrols, and when states deport migrants who cross borders or reside in a state's territory without authorization. People who endorse Restrict accept the permissibility of some policies that prevent foreigners 
from crossing borders, the deportation of unauthorized migrants who have lived in a state's territory for a short period of time, and perhaps also restrictions on access to citizenship.

Contrast Restrict with the following claim:

Deport. It is morally permissible for legitimate states to deport and denationalize their own citizens in virtue of the fact that these states have rights to selfdetermination.

I will refer to a policy of deporting a state's own citizens and stripping them of their citizenship as compatriot deportation. I take it that most adherents of Restrict would reject Deport. If Restrict entails Deport, then Restrict has seriously objectionable implications. In the next four sections, I will argue that if Restrict is true, then Deport is also true.

To motivate my argument, consider the following case. Suppose that Leticia is a citizen of the United States. Leticia has little formal education. She works as an unskilled laborer in a factory and cleans houses on the side. Leticia is poor. She consumes more in welfare benefits than she pays in taxes. Leticia has also adopted cultural practices and values that are different from the practices and values of most other citizens of the United States. Suppose that the government of the United States decides to deport Leticia and strip her of her citizenship. Imagine that public officials find another country that is willing to admit Leticia. Leticia is also a national of Mexico. The government of the United States will deport her to this country. Suppose that this is a popular decision. A large majority of citizens supports deporting Leticia and other citizens with the same demographic characteristics as Leticia.

When Leticia asks for an explanation for her deportation, public officials say,"the United States has a right to self-determination. Citizens have rights to shape the future character of this society and they care deeply about how their political community will evolve. Citizens have rights to shape who the 'self' is. In this case, we've decided to shape the character of our community by deporting and denationalizing you and other people like you." Some citizens add that as the United States has a right to freedom of association, the citizens of the United States have a right to disassociate with Leticia by expelling her from their association. Others argue that citizens have rights to control the values and character of the public culture and citizens have decided to exercise these rights by deporting Leticia and others like her. Some citizens and officials claim that citizens have ownership rights over the institutions and territory of the United States. This gives them the right to evict people from their collective property.

This example suggests that if rights to self-determination justify immigration restrictions, then these rights might also justify compatriot deportation. The reason is that rights to self-determination are rights to control access to a territory along with the benefits that states provide to the residents of this territory, such as access to public services, welfare benefits, or citizenship. If rights to self-determination are rights to control access to a territory and legitimate states have these rights, then it seems to follow that legitimate states have rights to restrict immigration. After all, immigration restrictions are means of controlling foreigners' access to a state's territory and the legal entitlements that the authorized residents and citizens of this state possess. States 
exercise control over access to their territories and membership rights by excluding foreigners via immigration restrictions. But states also can exercise control over access to their territories and the membership rights that they provide by deporting and denationalizing citizens. Compatriot deportation is just another way of exercising control over people's access to a state's territory and membership rights. So, if rights to self-determination are rights to control access to a territory and the benefits that states provide to residents and citizens, then rights to self-determination might justify compatriot deportation as well as immigration restrictions.

Yet it seems wrong for the government of the United States to deport Leticia and other citizens. More generally, it seems that Deport is false. States have deported their own citizens and permanent residents in the past. Before the 20th century, European states sometimes banished criminals (Gibney, 2013: 647-648). During the Great Depression, public officials in the United States forcibly repatriated tens of thousands of American citizens who were of Mexican descent (Balderrama and Rodriguez, 1995). More recently, some liberal democracies have considered implementing laws that would denationalize citizens who fight for terrorist groups. But most people now regard the deportation of ordinary citizens who are not criminals, terrorists, or enemy combatants to be seriously unjust.

Why is Deport false? Here is one plausible answer: a policy of deportation unjustly interferes with people's liberties and harms them. Deportation prevents people from exercising their rights to freedom of association and their economic liberties. After the government of a country deports a person, this person is no longer able to associate with her friends and family who live in this country. The person who is deported will also likely suffer a significant loss in her standard of living and must adapt to a new society. We have strong moral reasons to refrain from interfering with people's liberties and causing them harm. Furthermore, people's interests in self-determination are insufficiently weighty to justify interfering with valuable liberties and inflicting significant harm on people. For these reasons, Deport is false. ${ }^{3}$

If this is the correct explanation for why Deport is false, then it is unclear why Restrict is true. After all, immigration restrictions can also interfere with people's liberties and cause them harm. Immigration restrictions interfere with freedom of association. These restrictions prevent people from living with their friends and family in other states. Immigration restrictions also interfere with the economic liberties. Immigration restrictions prevent people from working for the employers of their choice in other countries, even if these employers are willing to hire them. Immigration restrictions set back people's interests in economic mobility. One group of economists (Clemens et al., 2008) finds that moderately skilled workers in the developing world can increase their real incomes by moving to rich countries. On average, these workers would increase their annual real income from about US $\$ 5000$ to US $\$ 15,000$ by immigrating to a high-income country when adjusting for purchasing power. Restrictions on border crossings stop people from escaping poverty and unemployment. If the moral reasons to refrain from infringing on people's liberties or causing them harm explain why compatriot deportation is unjust, then there is a question about why immigration restrictions are nonetheless permissible.

But it is also readily possible that there is some relevant difference between compatriot deportation and immigration restrictions. Perhaps Restrict is true and 
Deport is false on closer inspection. I will refer to the position that Deport is false and Restrict is true as The Asymmetry. I will now consider three major arguments for The Asymmetry. I will show that these arguments for The Asymmetry are unsound. I will conclude that we ought to reject The Asymmetry. Either both Restrict and Deport are false, or they are both true. More precisely, I will show that, if Restrict is true, then it is in principle permissible for states to deport and denationalize their own citizens, although there may be contingent reasons why a policy of compatriot deportation is infeasible. In other words, adherents of Restrict lack the resources to offer a principled reason for rejecting Deport. ${ }^{4}$

\section{The ownership argument}

Some authors argue that the citizens of a country have rights to inhabit this country's territory because citizens have ownership rights to the territory of this country or its political institutions (Miller, 2007; Pevnick, 2011). This is a version of the selfdetermination argument. On this view, states have rights to self-determination because the citizens of these states have ownership claims over the territories or institutions of these states. Citizens acquire ownership rights over a territory or political institutions by enhancing the value of this territory or contributing to the creation and maintenance of political institutions.

With this account of self-determination in mind, consider the following argument for The Asymmetry:

1. The citizens of a country have ownership claims over their territories or their political institutions.

2. If the government of this country deported and denationalized its own citizens, then this government would violate their ownership rights by preventing them from using and benefiting from this country's territory or institutions.

3. But foreigners lack ownership rights to a state's territory or political institutions.

4. So, immigration restrictions do not violate foreigners' ownership rights.

Call this the ownership argument. There are different versions of the ownership argument. One version of the ownership argument is collectivist. Collectivist versions of the ownership argument hold that individuals do not have ownership rights over a state's territory. Instead, certain groups or collective agents, such as nations or states, have ownership rights over their territories. Another version of the ownership argument is individualist. It says that the individual citizens of a state have ownership rights over this state's territory or political institutions. I will only consider individualist versions of the ownership argument in this section because collectivist versions of this argument are unable to rule out Deport. If groups rather than individuals have ownership rights, then it appears that states do not violate the ownership rights of individuals if states deport them. It is hard to see how the fact that groups have ownership rights would explain why it is wrong to deport individuals. So, it seems that only individualistic versions of the ownership argument can ground an objection to Deport. ${ }^{5}$

The ownership argument faces a dilemma. The ownership argument says that citizens have ownership rights to a state's institutions or territory because citizens 
contribute to these institutions or increase the value of this territory. Yet some foreigners also contribute in these ways. If foreigners also contribute in these ways, then either foreigners have ownership rights or they do not have these rights because they do not contribute enough. If foreigners have ownership rights, then it is wrong for states to restrict their immigration. If foreigners lack ownership rights because they do not contribute enough, then it is surely the case that some citizens also lack these rights for the same reason. Thus, states would not violate the rights of these citizens by deporting them. Either way, the ownership argument fails to justify The Asymmetry.

To explain this dilemma, I will begin by focusing on Ryan Pevnick's version of the ownership argument. According to Pevnick, citizens acquire ownership claims to a state's institutions if they contribute to the creation and maintenance of these institutions. Citizens might contribute by obeying the law, paying taxes, and participating in political decision-making (Pevnick, 2011: 35). If citizens have ownership rights to political institutions, then they have rights to benefit from and use these institutions on an equal basis with other co-owners.

But, if Pevnick's account of what grounds ownership claims is correct, then his account is unable to support The Asymmetry. The problem is that foreigners also contribute to a state's political institutions. Here is an example. Suppose that Dani is a citizen of Turkey. Dani's business exports manufacturing goods to Germany. To do this, Dani must pay tariffs that the German government collects. Dani pays much more in tariffs than most German citizens do in taxes. Dani also has family in Germany and he often sends them money and visits them for short periods of time as a tourist, but the German government forbids him from immigrating permanently. When Dani is in Germany, Dani always obeys the law.

Dani contributes to the maintenance of political institutions in Germany by paying taxes and obeying the law. So, it would seem that Dani has an ownership claim to German institutions. If Dani has an ownership claim to German institutions, then he has a right to benefit from and use these institutions. If so, then it appears that the German government violates his ownership rights to these institutions by preventing him from fully benefiting from these institutions by immigrating permanently to Germany. More generally, foreigners often contribute to maintenance of other countries' institutions through trade, the maintenance of peaceful relationships, and foreign direct investment. Yet perhaps Dani does not contribute enough to German institutions to acquire ownership claims to them. Maybe people must satisfy some threshold of contribution for them to acquire ownership rights to political institutions. But many German citizens appear to contribute to these institutions even less than Dani. Some German citizens break the law and do not pay taxes. Other German citizens, such as young children, also do not contribute as much as Dani. So, if Dani lacks ownership rights to German institutions, then some German citizens also lack these rights. ${ }^{6}$ Thus, the German government would not violate the ownership rights of these citizens if the government deported them.

Other individualistic versions of the ownership argument confront the same dilemma as Pevnick's account. ${ }^{7}$ Consider the following version of the argument. Suppose that citizens acquire rights to inhabit a country's territory by improving the value of this territory. In particular, citizens improve the value of public space by constructing roads and bridges, wells, public parks, historical monuments, and so on. 
These activities improve the value of a territory by increasing a society's capacity to provide decent lives for its residents. If citizens improve the value of a territory, they acquire ownership rights to the value that is embodied in this territory. ${ }^{8}$ It is wrong to deport citizens because they have ownership claims to the value that is embodied in a specific territory. If states deport citizens, then these states violate citizens' ownership rights. But perhaps foreigners do not have ownership rights to the territory of another state because foreigners do not improve the value of the land in other states.

Yet foreigners can contribute to increasing the value of another country's territory. Foreigners can even contribute to increasing the value of a territory without ever setting foot on this territory. Here is an example. Suppose that the citizens of country A drain a malarial swamp that sits near another country B's border. This raises the value of land in country B by making this land less hazardous to the citizens of country B. So, perhaps the citizens of A acquire ownership rights to the increased value of B's territory. This example is not just an odd exception. Economic activity typically has positive spillover effects. The economic activities of the citizens of one country often raise the value of another country's territory. If citizens of one country construct institutions that allow this country to prosper, this will likely increase economic output as well as the value of land in neighboring countries.

If people acquire ownership rights to another state's territory by raising the value of this territory, then it seems that foreigners should have rights to inhabit this territory as well. Presumably, if foreigners have rights to inhabit a territory, then they have rights to immigrate there. If so, then Restrict is false: it is often wrong for states to restrict immigration because doing so violates the ownership rights of foreigners. But perhaps people's contributions must meet to some threshold of value for them to acquire claims to inhabit this land. Foreigners may not contribute enough to acquire claims to inhabit a state's territory. But then it will likely be the case that some citizens also do not contribute enough to acquire claims to inhabit this territory. To take an obvious example, young children and the severely disabled may contribute less to improving the value of a nation's territory than some foreigners. These citizens may lack claims to reside in a state's territory. If some citizens lack rights to reside in a state's territory, then the state does not violate their claims by deporting them. In that case, Deport is true. It therefore appears that the ownership argument and structurally similar arguments are unlikely to justify The Asymmetry.

\section{The harm argument}

Another argument for The Asymmetry might appeal to the harm that deportation causes. Deportation tears people away from their friends, family, and culture. But perhaps immigration restrictions do not cause harm. Instead, immigration restrictions merely withhold benefits to potential immigrants, particularly the benefit of admission to a state. Furthermore, a state's right to self-determination can outweigh the moral reasons to provide potential immigrants with benefits, while a right to selfdetermination fails to outweigh the moral reasons to refrain from harming citizens. In other words, this argument goes as follows:

1. Deportation causes harm to people. 
2. Immigration restrictions do not cause harm-when states restrict immigration, they merely withhold benefits from potential immigrants.

3. The moral reasons to refrain from causing harm are stronger than the moral reasons to refrain from withholding benefits.

4. A legitimate state's right to self-determination generally outweighs the moral reasons to refrain from conferring benefits on potential immigrants, but this right does not outweigh the moral reasons to refrain from causing harm.

5. So, compatriot deportation is unjust, while immigration restrictions are generally permissible.

Call this: the harm argument. The problem with the harm argument involves premise 2 . The claim that immigration restrictions only involve the withholding of benefits is false. Immigration restrictions also cause harm.

To illustrate, consider the following analogy. Imagine that Bradley lives in a lowincome neighborhood. Most of the jobs in Bradley's neighborhood pay relatively little. If Bradley works in his neighborhood, then Bradley would live in poverty. But Bradley lives in a large city. Bradley can find a job outside of his neighborhood that pays enough to allow him to escape poverty. Imagine that the local government decides to forcibly prevent the residents of Bradley's neighborhood from leaving and entering other parts of the city. The government sends police officers to patrol the outskirts of Bradley's neighborhood and coercively prevent people from leaving. As a result, Bradley is forced to remain in his neighborhood and continues to live in poverty. ${ }^{9}$

It is false that the government merely denies Bradley benefits by preventing him from leaving his neighborhood. It seems clear that the government has harmed Bradley. More precisely, the government enables harm to Bradley. Agent A enables harm to person B if A acts in a manner that prevents B from avoiding harm (Barry and Øverland, 2011). The police enable harm to Bradley by creating an obstacle that prevents him from escaping poverty. If poverty is a harmful state of affairs, then the government causes harm to Bradley. Enabling harm is a kind of causing harm. When an agent enables harm, this agent initiates a causal sequence that results in harm to another person by preventing this person from avoiding harm. So, if person A enables harm to person B, person A causes harm to person B. Immigration restrictions can cause harm in this sense. Immigration restrictions create obstacles that prevent people from escaping the harms associated with poverty, unemployment, violence, and other bad states of affairs.

But perhaps compatriot deportation would cause more harm to denationalized citizens than the harm that immigration restrictions inflict on potential immigrants. Along these lines, consider a modified version of the harm argument:

1. Compatriot deportation would cause greater harm to the people who are deported and denationalized than the harm that immigration restrictions cause to potential immigrants.

2. Everything else being equal, states have stronger moral reasons to refrain from inflicting greater harms.

3. So, states' moral reasons to refrain from deporting their citizens are stronger than states' reasons to admit potential immigrants. 
4. A legitimate state's right to self-determination generally outweighs the moral reasons to refrain from causing lesser harms to potential immigrants by restricting immigration, but this right does not outweigh the moral reasons to refrain from causing harm to citizens by deporting them.

5. So, compatriot deportation is unjust, while immigration restrictions are generally permissible.

Call this the greater harm argument.

A defender of the greater harm argument might point to the various social relationships and connections that people form when they live in a society. When people live in a society for a significant period of time, they form friendships, familial relationships, and become members of communities (Carens, 2010: 3-20). People also form plans on the assumption that they will permanently live in a society. People may choose to pursue a certain career because they expect that they will remain in a society for a long period of time. Deportation damages the integrity of people's social relationships and sets back their personal projects. If a state deports a person and strips this person of citizenship, then this state may cause this person to be stateless. Stateless people often lack secure access to basic rights and protections.

A policy of deportation would cause harm to other people besides the deportees. If states adopt a policy of deporting citizens, this would cause harm to their friends and family members, especially their dependents. A policy of deportation could also cause more subtle harms. Even if a state does not actually deport many citizens, a policy of compatriot deportation would make many citizens vulnerable to deportation. Citizens would feel less secure about their residency in a state and this would impair their ability to make long-term plans. This vulnerability could have other bad effects. For instance, compatriot deportation might stifle political dissent because citizens would fear that governments would deport dissenters. Compatriot deportation could also generate invidious inequalities. Denationalization laws in the past have only allowed states to deport and strip citizenship from naturalized citizens, not the native born (Gibney, 2013: 652). Denationalization may create a group of second-class citizens. If states implemented denationalization laws, perhaps native-born citizens would be immune from deportation, while naturalized citizens would be liable to denationalization and deportation.

According to the greater harm argument, the harms of immigration restrictions are less grave than the harms of deportation. Immigration restrictions frustrate people's desires to live in another society. But foreigners generally have fewer social connections to the members of recipient societies and their plans and projects may not depend on immigrating to another state. Immigration restrictions also do not generally cause statelessness. People who are denied admission to a state retain their citizenship in another state. The greater harm argument concedes that states have rights to selfdetermination, but holds that these rights can be outweighed by the moral reasons to avoid causing harm. As compatriot deportation causes more harm than immigration restrictions, states' moral reasons to refrain from deporting citizens outweigh states' rights to self-determination.

But it is unclear whether compatriot deportation would cause more severe harm than immigration restrictions. To get a sense of the magnitude of the harm that immigration 
restrictions cause, consider some quantitative estimates of the losses that immigration restrictions inflict on the citizens of developing countries. Economists estimate that more open immigration would bring about massive benefits to the residents of the developing world. The economist Michael Clemens (2011: 84) surveys different estimates on the global economic effects of open borders and finds that open immigration could more than double the size of the global economy. Most of these gains would flow to the residents of poor countries. In a recent study, John Kennan (2013) investigates the effects of open borders on the incomes of all workers in 40 countries. The average income per worker in these countries is US\$8633. Kennan finds that open borders would raise the average annual income per worker (including nonmigrants) by US $\$ 10,798$ or about $125 \%$. Other evidence suggests that more liberal immigration policies would benefit the citizens of the developing world far more than trade liberalization (Clemens, 2011: 85). If rich countries lowered their immigration restrictions, this might cut global poverty into half (Bradford, 2012).

These estimates suggest that immigration restrictions cause significant harm to people developing countries by preventing them from avoiding poverty. It is also worth pointing out that immigration restrictions damage many of the same interests that compatriot deportation sets back. Immigration restrictions interfere with the integrity of people's social ties. People can form social relationships and ties across states. They can have friends and family members in other states. They can have ties to coreligionists or members of their culture in another state as well. Immigration restrictions can undermine with the integrity of these social connections. Some people also make their plans and pursue their projects on the assumption that they will immigrate. Health workers in developing countries often decide to become doctors or nurses because they anticipate that this will make it easier for them to immigrate abroad (Gibson and McKenzie, 2011: 118-120). Immigration restrictions interfere with their plans. Immigration restrictions also have harmful effects on third parties. People often send remittances home after they immigrate. Immigrants send about US $\$ 400$ billion in remittances to their dependents and compatriots every year and these remittances seem to reduce poverty (Clemens, 2011: 99). Immigration restrictions prevent people from immigrating and thereby reduce the volume of remittances.

Immigration restrictions cause vulnerability as well. Immigration restrictions reduce exit options. These restrictions make people more vulnerable to harm even if they have no plans or desires to immigrate. If people lack the option of immigrating, this increases their vulnerability to human rights violations and unjust laws in the country where they currently reside. Suppose that Inmer lives in a country that is prone to civil wars and economic shocks because the economy of Inmer's country is dependent on natural resources and the price of these resources is volatile. Inmer does not want to immigrate. But suppose that other countries would refuse to admit Inmer if Inmer tried to immigrate. Immigration restrictions make Inmer more vulnerable. Inmer is vulnerable to political violence if civil war breaks out. Inmer is also vulnerable to poverty and unemployment if his country's economy suffers a sudden economic shock. In this sense, people who lack the option of immigrating become more vulnerable to sudden economic downturns, technological shocks, natural disasters, and oppressive laws. 
Finally, it is not true that compatriot deportation invariably causes stateless or invidious inequalities. Consider the following scheme (Gibney, 2013: 655). Imagine that the government of the United States agrees to a treaty with the government of Mexico. The Mexican government agrees to admit anyone that the United States decides to deport. With this arrangement in place, the government of the United States can deport any of its citizens without causing them to be stateless regardless of whether these citizens currently have citizenship in another country. So, the government could deport both naturalized and native-born citizens on an equal basis. Obviously, no such scheme currently exists. But the possibility of this treaty shows that the compatriot deportation would not necessarily cause statelessness and invidious inequalities.

Even if a policy of compatriot deportation causes more harm than immigration restrictions in general, the greater harm argument is consistent with the permissibility of compatriot deportation in certain cases. Consider some examples to help illustrate. Suppose that Sam is a citizen of the United States. But Sam has few ties and social connections in the United States and Sam also has few long-term plans. The government of the United States deports Sam to Norway where Sam also has citizenship. This deportation damages Sam's social connections and frustrates some of his projects. Sam must also adjust to Norwegian culture. But Sam is a resilient and adaptable person. Moreover, Sam still lives in a wealthy liberal democracy. Sam can avoid severe poverty, political instability, or persecution. Norway may even be a more attractive place for Sam to live than the United States in certain respects. Sam would like to live in a society with less poverty and inequality than the United States and would benefit from Norway's generous social insurance programs.

Contrast Sam's case with the case of Kwame. Kwame lives in a middle-income country. This country is a liberal democracy and can generally satisfy the basic needs of its citizens. Kwame works as a mechanic and has access to enough resources and options to live a decent life. But Kwame is poorer than most of the citizens of highincome states. Furthermore, Kwame wants to attain a higher standard of living and dreams of becoming an engineer, but there are few engineering schools in the country where he lives. For these reasons, Kwame wants to immigrate. But the governments of rich states refuse to admit him. As a result, Kwame continues to work as a mechanic in his own country and abandons his dream of becoming an engineer.

Sam's deportation might cause him less harm than the harm that immigration restrictions cause to people like Kwame. If it is permissible for rich states to prevent people like Kwame from immigrating, then it appears that the greater harm argument is consistent with Sam's deportation. One might respond that public officials lack the ability to differentiate between cases when deportation would cause severe harm to deportees and cases when it would only cause lesser harms. For this reason, hypothetical cases like Sam's and Kwame's cases have little bearing on the justification of actual public policies and laws. But my point is not that compatriot deportation is justified as a matter of actual public policy. My point is that adherents of Restrict lack the resources to explain why compatriot deportation is in principle unjust. If public officials could accurately determine when deportation would cause relatively little harm to citizens, then it would be permissible for states to deport their citizens in these cases. 
So, the greater harm argument has two problems. First, we have reasons to doubt whether compatriot deportation would cause less harm than immigration restrictions. Second, even if compatriot deportation would cause more harm than immigration restrictions in general, compatriot deportation would cause less harm than immigration restrictions in some cases. The greater harm argument is unable to explain why deportations are morally impermissible in these cases. Thus, this argument fails to justify The Asymmetry.

\section{The partiality argument}

In the previous section, I assumed that states' moral reasons to refrain from harming their citizens and the moral reasons to avoid harming potential immigrants are equally weighty. But perhaps this assumption is false. Many people think that the citizens of a state have special obligations to one another. Citizens have strong moral reasons to refrain from causing harm to their compatriots by deporting them. But citizens lack the same strong moral reasons to protect the interests of potential immigrants. This suggests the following argument for the asymmetry:

1. The citizens of a state have special obligations to one another and they do not have these obligations to foreigners.

2. If the citizens of a state have special obligations to one another and they do not have these obligations to foreigners, then the citizens of this state have stronger moral reasons to protect each other's interests than they have to protect the interests of foreigners.

3. So, citizens' moral reasons to refrain from deporting and denationalizing compatriots are stronger than their reasons to permit immigration.

4. A legitimate state's right to self-determination generally outweighs the moral reasons to permit immigration, but this right does not outweigh the (stronger) moral reasons to refrain from deporting citizens.

5. So, compatriot deportation is unjust, while immigration restrictions are (at least generally) permissible.

Call this the partiality argument..$^{10}$ The partiality argument offers a certain explanation for why it is wrong to deport citizens. Citizens may have special relationships with one another that activate obligations. Some authors argue that compatriots share valuable relationships that justify associative duties to one another (Miller, 2007: 37-43). If compatriots have special obligations to one another, they have distinctive moral reasons to protect each other's interests. Citizens would violate these obligations if they deported their compatriots. But the citizens of a state do not have special obligations to foreigners. Perhaps the citizens of a state and foreigners lack the right kind of relationship to activate special obligations. According to the partiality argument, the moral reasons that explain why the deportation of citizens is impermissible fail to condemn immigration restrictions.

I will assume the premise that we have special obligations to our compatriots. But, even if this premise is true, the partiality argument is problematic. As I noted in the previous section, immigration restrictions cause harm. Compatriot deportation would 
also cause harm. The partiality argument holds that it is worse to harm one's compatriots than it is to harm foreigners. The partiality argument rests on the assumption that special obligations magnify the strength of negative duties, duties to refrain from causing harm to people. The idea is that it is morally worse for person A to harm person $\mathrm{B}$ if $\mathrm{A}$ has a special obligation to $\mathrm{B}$ than it is for $\mathrm{A}$ to harm $\mathrm{B}$ if $\mathrm{A}$ lacks a special obligation to $\mathrm{B}$. This claim must be true for the partiality argument to succeed because the partiality argument holds that it is morally worse for citizens to deport their compatriots in virtue of the fact that citizens have special obligations to their compatriots. But the fact that $\mathrm{A}$ has a special obligation to $\mathrm{B}$ does not seem to significantly affect the strength of A's negative duties to refrain from causing harm to B. At least, the strength of our moral reasons to avoid harming other people does not seem to vary depending on whether they are our compatriots.

Consider the following case:

Compatriot Mugging. Bradley is walking down a dark alley at night. A mugger assaults Bradley and takes his wallet. After looking through Bradley's wallet, the mugger realizes that he and Bradley are citizens of the same state.

Contrast Compatriot Mugging with:

Foreigner Mugging. Susan is walking down a dark alley at night. A mugger assaults Susan and takes her wallet. After looking through her wallet, the mugger realizes that Susan is a tourist from another country.

The mugger's actions in both cases are impermissible. But the mugger's actions in Compatriot and Foreigner Mugging also seem to be equally impermissible. It would be odd to claim that the mugger should feel worse about his actions in Compatriot Mugging once he realizes that Bradley was his compatriot. The fact that the mugger harms his compatriot rather than a foreigner in Compatriot Mugging fails to affect the seriousness of the mugger's wrongdoing. Even if the mugger has a special obligation to his compatriots, this special obligation does not appear to influence the strength of the mugger's moral reasons to refrain from harming other people.

This conclusion casts doubt on the claim that it is wrong for states to deport their citizens because compatriots have special obligations to one another. The partiality argument claims that it is wrong to cause harm by deporting compatriots but it is permissible to cause harm by restricting immigration because compatriots have special obligations to one another. But, as we have seen, the existence of special obligations to compatriots does not significantly affect the strength of our negative duties. For this reason, special obligations to compatriots are unable to explain why the deportation of citizens is wrong while immigration restrictions are permissible. If we ought to reject the explanation that the partiality argument gives for the impermissibility of compatriot deportation, then the partiality argument also fails to justify The Asymmetry.

This rejection of the partiality argument may be too hasty. There might be a better version of the partiality argument than the one that I have considered. Perhaps we should focus on the special obligations that governments owe to their citizens rather than the special obligations between compatriots in general. The view that compatriots 
owe special obligations to one another is controversial. But it is less controversial to claim that governments have special obligations to their citizens. Some theorists believe that governments have duties of care or fiduciary duties to their citizens (Criddle and Fox-Decent, 2009). On this view, governments have special duties to protect the rights and interests of their citizens in particular. If the governments of states have special fiduciary duties or duties of care to their citizens, then these duties might explain why it is wrong for governments to deport their own citizens. But governments do not have these special duties to potential immigrants. So, states' duties of care to their citizens explain why it is wrong to deport their citizens, but these duties do not entail that it is impermissible to restrict immigration.

But this version of partiality argument does not avoid the objection that the original version of the argument confronts. The existence of fiduciary duties or duties of care do not seem to sufficiently alter the strength of our negative duties to avoid harming other people to justify The Asymmetry. Consider an analogy. Suppose that Bradley is the legal guardian of a child. Legal guardianship is generally thought to impose fiduciary duties on the guardian. Bradley must do more for his child than for other children. In other words, Bradley has stronger and more extensive positive duties to his child than he does to other people's children (positive duties are duties to provide aid or assistance to another person). Bradley must provide his child with adequate shelter, food, and education. If Bradley fails to adequately care for his child, then he is culpable of negligence. Yet Bradley's negative duties seem to be unaffected by his fiduciary responsibilities. It would be wrong for Bradley to physically abuse his child. But it would also be wrong for Bradley to physically abuse some other person's child too. This fact suggests that the existence of Bradley's fiduciary duty fails to explain why it is wrong for Bradley to harm his child in particular. Maybe the existence of this duty makes is slightly worse for Bradley to harm his own child. But the central explanation for why it would be wrong for Bradley to harm his child is that Bradley has general negative duties to refrain from harming other people, including his own child. Bradley's fiduciary duty to his own child seems to be mostly irrelevant to explaining why it is wrong for Bradley to abuse his child.

Perhaps states also have fiduciary duties to protect the interests of their citizens. If so, then states have stronger positive duties to benefit their citizens than foreigners. It is plausible that states are under obligations to provide their citizens with certain positive benefits, such as protection, access to education, welfare benefits, and so on, and that states lack duties to provide these benefits for foreigners in other countries. But, like in the case of Bradley's guardianship, the strength of a state's negative duties also seems unaffected. At first glance, it seems that compatriot deportation is wrong primarily because compatriot deportation would cause harm and public officials have negative duties to refrain from causing harm. However, if compatriot deportation is unjust because it would involve the violation of negative duties, then it is unclear how we can distinguish compatriot deportation from immigration restrictions. After all, immigration restrictions also inflict harm and may therefore violate negative duties. For these reasons, the partiality argument does not support The Asymmetry.

\section{Rejecting restrict}


I have now evaluated the three major arguments for the Asymmetry. These strike me as the most plausible arguments available in favor of this position. The fact that all of these arguments are unsound gives us reason to conclude that The Asymmetry is false. If my arguments against The Asymmetry are sound, then we must either accept or reject both Deport and Restrict. But my arguments against The Asymmetry are, strictly speaking, neutral with respect to the truth of Restrict and Deport. They do not show that Restrict and Deport are false. They only show that we are unable to affirm Restrict without accepting Deport. But I will now argue we should reject both Restrict and Deport.

One reason to reject Restrict and Deport appeals to reflective equilibrium. According to a standard method of moral inquiry, the fact that a moral principle or view has implications that conflict with our considered moral convictions is a reason to reject this principle or view (Rawls, 2005: 8-9). Many people appear to have the considered conviction that it is unjust for states to deport and denationalize citizens. The Inter-American Commission on Human Rights articulated this standard view when it declared that "the expulsion of a citizen by his own government is, under normal circumstances, absolutely precluded by human rights norms" (Hannum, 1987: 64). Consider contemporary attitudes about the mass expulsion of Mexican Americans from the United States during the Great Depression. This event is now regarded as a shameful episode in American history. Public officials in the United States have apologized for the mass deportation of Mexican Americans and acknowledged that this policy violated the rights of these citizens (Koch, 2006). As this example illustrates, the view that it is morally wrong for states to deport and denationalize ordinary, noncriminal citizens is widely accepted. The self-determination argument implies the compatriot deportation is morally permissible and, so, this argument has implications that are inconsistent with considered moral judgments. We therefore have a strong reason to reject the self-determination argument.

This objection to the self-determination argument goes:

1. If states' can permissibly restrict immigration in virtue of the fact that they have rights to self-determination, then it is morally permissible for states to denationalize and deport innocent, law-abiding citizens.

2. It is impermissible for states to denationalize and deport innocent, law-abiding citizens.

3. So, it is impermissible for states to restrict immigration in virtue of the fact that they have rights to self-determination.

Of course, defenders of the self-determination argument might reject the second premise of this argument. They might bite the bullet and accept that compatriot deportation is permissible. Yet the fact that the self-determination argument implies Deport may be a symptom of a more fundamental problem with this argument. The striking fact about the self-determination is that it also justifies restricting the liberties of a state's citizens as well as the liberties of foreigners. The self-determination argument holds that the citizens of a legitimate state have rights to shape and control the future direction of their societies. Citizens can exercise these rights by limiting immigration. But, if citizens have liberty-rights to restrict people's freedom to 
immigrate, then perhaps citizens have liberty-rights to exercise their rights to selfdetermination by restricting other freedoms as well.

Consider an example. Suppose that most citizens of a legitimate state are deeply religious, although a small minority are atheists. Religious citizens are offended when people insult their religious beliefs. In a referendum, a large majority of citizens vote in favor of a law that bans blasphemy. This law will penalize people who publicly insult or express contempt for religious beliefs and practices. It is possible to construct a selfdetermination argument for restrictions on speech. Anti-religious rhetoric can influence how the public culture of a society develops. For instance, anti-religious speech might influence fewer people to become religious. [AQ4]But citizens have strong interests in controlling their public culture. For this reason, states may have presumptive rights to restrict anti-religious speech. Alternatively, we might argue that citizens have ownership rights over their state's territory and political institutions. The owners of private property have limited rights to restrict the speech of people who occupy their property. Perhaps citizens as a whole can decide to restrict religious speech on their collectively owned territory. We can also invoke states' rights to freedom of association to justify restrictions speech. Religious organizations and clubs can permissibly require members to refrain from committing blasphemy as a condition of their membership. Similarly, the citizens of legitimate states can exercise their rights to freedom of association by requiring their fellow citizens to abstain from insulting religious practices and beliefs.

Defenders of Restrict might deny that rights to self-determination would justify restrictions on speech. One could argue either that rights to self-determination do not provide even presumptive support for restrictions on speech. But it is hard to explain why rights to self-determination would presumptively justify immigration restrictions and nonetheless fall short of presumptively justifying other restrictions on liberty. After all, citizens can justify the above restrictions on speech on the same grounds as defenders of Restrict can justify immigration restrictions. Advocates of restrictions on speech can argue that these laws are necessary to maintain control over the public culture, exercise ownership rights over a country's institutions or territory, or exercise rights to freedom of association. One might argue that immigration restrictions are enforced against foreigners, while the above laws are enforced against the citizens of a state. But it is unclear why this would make a difference. As I have shown, special obligations to compatriots do not significantly alter the strength of negative duties. So, citizens' special obligations to one another fail to explain why Restrict is true but the above laws are unjust. Furthermore, immigration restrictions are also typically enforced against citizens. These restrictions prevent the citizens of a state from employing potential immigrants or living with their friends and family if they are foreigners.

Defenders of Restrict might instead respond that interference with freedom of speech is an unacceptable infringement on liberty and that rights to self-determination do not outweigh people's liberty-interests in these cases. But immigration restrictions also interfere with important liberties. They interfere with both the liberties of potential immigrants and the liberties of citizens who want to associate with these foreigners. This infringement on liberty is hardly trivial. If the freedom to immigrate were trivial or unimportant, it would be hard to make sense of the fact that hundreds of thousands of people risk incarceration, injury, and death every year in attempts to evade 
immigration restrictions. So, it is unclear why people's interests in freedom of speech would categorically outweigh rights to self-determination, while rights to selfdetermination sometimes outweigh people's rights to immigrate or associate with immigrants. The claim that rights to other liberty-interests always outweigh rights to self-determination and that rights to self-determination generally outweigh rights to immigrate or associate with immigrants appears to be simply ad hoc.

My example of free speech is one example of how the self-determination has other objectionable implications, besides Deport. There are other examples too. Sune Lægaard gives another example. Lægaard (2013) observes that immigration

is not the primary or most important source of reproduction of the collective; it is mainly reproduced by existing members giving birth to children who usually become members of the people automatically. If the existing collective has a right to control what it is going to be in the future, this not only means that it can exclude would-be immigrants, but also that it can direct its reproduction through birth.

Lægaard argues that if states have rights to control their composition and membership, then they also have rights to control their population growth through coercive measures, such as measures that forbid citizens from having more than one child. Immigration changes the composition and character of a society: children are like immigrants from the future. If citizens can permissibly use coercion to control membership via immigration, then it is unclear why citizens are unable to permissibly control membership via restrictions on reproductive freedom.

So, if Restrict is true, then we might be able to construct parallel arguments for restrictions on other valuable freedoms besides the freedom to immigrate. This is a strong reason to suspect that there is something fundamentally wrong with the selfdetermination argument. Where exactly does the argument go wrong? Here is a simple and parsimonious account that explains why both Restrict and Deport are false. Rights to self-determination are rights to control other people's behavior by controlling their movement across borders and their residency in a society (and perhaps in other ways too). People care about their political communities and how the distribution of membership affects the character and cultures of these communities. Yet people's interests in controlling the behavior of other people do not justify liberty-rights to interfere with valuable individual freedoms. The moral reasons to respect individual freedom in general defeat states' claims to self-determination in cases where these values conflict. Most of us already accept that rights to self-determination do not justify compatriot deportation and restrictions on other important freedoms. But the adherents of the self-determination argument fail to recognize how the same moral reasons that decisively outweigh a community's right to self-determination in these cases also decisively outweigh a community's right to exclude foreigners. The value of selfdetermination falls short of grounding liberty-rights to restrict people's freedom to cross borders, just as the value of self-determination fails to ground liberty-rights to deport citizens and interfere with other important liberties. ${ }^{11}$

\section{Conclusion}


In this article, I argued that one prominent argument for immigration restrictions, the self-determination argument, has objectionable implications. This argument entails that it can be morally permissible for states to denationalize and deport their own citizens. To avoid this implication, we should reject the self-determination argument. We should reject the conclusion that rights to self-determination can justify any significant immigration restrictions.

\section{Notes}

1. David Miller (2012) endorses this view (p. 254). In contrast, Christopher Wellman (2008) claims that states have rights to self-determination, not nations or cultural communities (pp. 113-114, 117-119). My objection to the self-determination argument will apply to both "nationalist" and "statist" conceptions of self-determination.

2. How exactly is collective self-determination different from state sovereignty? State sovereignty is a legal institution. Sovereignty gives states legal or conventional rights, such as legal rights against interference, the power to make treatises, and so on. In contrast, rights to self-determination are moral rights. If states have them, then these states have moral rights against interference and perhaps other rights. But sovereignty and self-determination are connected. For example, state sovereignty may protect moral rights to self-determination by institutionalizing the norm of non-interference. Many people also think that state sovereignty implies that states have the legal authority to freely exclude outsiders. That may be true, but my question in this article is different: does the value of self-determination justify moral rights to exclude outsiders?

3. An objector might argue that this explanation of why Deport is false omits an important consideration: compatriot deportation would infringe on the political rights of citizens. Citizens have rights to participate in political decision-making and help shape their collective affairs through voting and other forms of political participation. But the deportation and denationalization of citizens would deprive people of the ability to participate in shaping the affairs of their community. So, compatriot deportation would violate political rights. I concede that this is one reason against compatriot deportation, but it is doubtful that it is the main explanation for why compatriot deportation is unjust. For one thing, it seems possible to denationalize and deport citizens without denying them political rights. Although this is an unlikely scenario, it is possible for a state to strip a citizen of most her membership rights, deport her to another state, deny her the right to return, and nonetheless allow her to cast absentee votes, petition government officials, and otherwise participate in political decision-making from abroad. If compatriot deportation would still be wrong in this case (and it clearly is), then it appears that other considerations unrelated to political rights explain why this practice is unjust. I want to thank an anonymous referee for raising this issue.

4. Other authors (Cole and Wellman, 2011: 193-204) have advanced the similar argument that rights to control immigration entail rights to restrict emigration and that this is a reason to reject the view that states have rights to control immigration.

5. It is not entirely clear whether David Miller endorses a collectivist or individualistic version of the ownership argument. Miller (2012: 258) seems to suggest that a nation is the bearer of territorial rights rather than individual people.[AQ5]

6. Pevnick (2011: 61-63) considers the objection that foreigners have ownership claims because they contribute to international organizations and institutions. Pevnick argues that these international institutions are insufficiently important to ground ownership rights. But Pevnick neglects to consider the argument that I am giving here. My claim is not that foreigners have ownership rights because they contribute to international institutions. 
Instead, my claim is that foreigners often contribute to the domestic institutions of other states. If this is the case, either some foreigners have ownership rights to the institutions of other states or some of the citizens of these states lack these rights.

7. Pevnick (2011) does briefly address the issue of compatriot deportation (pp. 64-66). But Pevnick argues that even citizens who lack ownership claims have rights to citizenship because citizens are non-voluntarily "enmeshed" in a system of social cooperation with other citizens that determine their life chances and this entitles them to citizenship rights. While Pevnick does not fully explain this argument, he seems to endorse the following principle (call this principle $P$ ): Person A is entitled to membership rights (like citizenship) if $\mathrm{A}$ is non-voluntarily subject to institutions I and membership rights are crucial for A to secure important goods under I. But it is hard for me to see how this principle can justify a distinction between citizens and potential immigrants. Foreigners and citizens are also nonvoluntarily "enmeshed" in common cooperative schemes. In particular, potential immigrants are non-voluntarily subject to at least one major institution: the state system along with a system of international law that gives states the legal discretion to exclude outsiders. Furthermore, membership rights in other states are often crucial for people to secure urgent goods. So, potential immigrants are non-voluntarily subject to social institutions (the state system) and membership rights in other states are crucial for securing important goods. If so, then $P$ would seem to entail that many foreigners have entitlements to citizenship in other states, which presumably means that these foreigners have rights to immigrate to these states. Thus, $P$ also cannot justify The Asymmetry.

8. Miller (2012: 258-261) sketches an argument along these lines, although, as I noted above, Miller may only accept a collectivist version of the argument.

9. Michael Huemer (2010: 431-436) gives a similar example to show that immigration restrictions cause harm.

10. While I am unaware of any philosopher who has explicitly defended the partiality argument, some political theorists (Macedo, 2008) do defend the related argument that special obligations between compatriots justify immigration restrictions when immigration imposes costs on the citizens of a state.

11. To clarify, I have endorsed two different lines of argument in section 7:

a. The self-determination argument has entailments that conflict with considered moral convictions and this is a strong reason to believe that this argument is unsound.

b. The same general considerations that explain why rights to self-determination do not justify compatriot deportation also explain why right to self-determination does not justify immigration restrictions.

I accept the following principle: if a moral view or principle has implications that conflict with our considered moral convictions, then this is a strong reason to reject this view or principle. We have the considered conviction that compatriot deportation is unjust. So, we have strong reasons to reject the self-determination argument. This is claim (a). I think that (a) is true irrespective of whether the same considerations that explain why compatriot deportation is unjust also explain why immigration restrictions are unjust. In my view, the fact that the self-determination argument has unacceptable entailments is a reason to reject it even if (b) is false. But I also happen to endorse (b). My objection to the self-determination argument should, I think, compel adherents of this argument to recognize that the same general considerations that condemn compatriot deportation also condemn immigration restrictions and other coercive infringements on liberty. I want to thank an anonymous referee for pushing me to clarify this point.

\section{References}


Abizadeh A (2008) Democratic theory and border coercion: No right to unilaterally control your own borders. Political Theory 36(1): 37-65.

Balderrama F and Rodriguez R (1995) Decades of Betrayal: Mexican Repatriation in the 1930s. Albuquerque, NM: University of New Mexico Press.

Barry C and Øverland G (2011) The feasible alternatives thesis: Kicking away the livelihoods of the global poor. Politics Philosophy Economics 11(1): 97-119.[AQ6]

Bradford S (2012) The global welfare and poverty effects of rich nation immigration barriers. Working Paper, Brigham Young University. Available at: https:/www.gtap.agecon. purdue.edu/resources/download/5857.pdf (accessed 20 February 2014).

Carens J (2010) Immigrants and the Right to Stay. Cambridge, MA: The MIT Press.

Clemens M (2011) Economics and emigration: Trillion dollar bills on the sidewalk? Journal of Economic Perspectives 25(4): 83-106.

Clemens M, Montenegro C and Pritchett L (2008) The place premium: Wage differences for identical workers across the U.S. border. Center for Global Development, Working Paper No. 148, July $3^{\text {rd }}$. Available at: http://www.cgdev.org/publication/place-premium-wagedifferences-identical-workers-across-us-border-working-paper-148 (accessed 24 June 2014). [AQ7]

Cole P and Wellman C (2011) Debating the Ethics of Immigration. New York: Oxford University Press.

Criddle E and Fox-Decent E (2009) A fiduciary theory of Jus Cogens. The Yale Journal of International Law 34: 331-387.

Gibney M (2013) Should citizenship be conditional? The ethics of denationalization. Journal of Politics 75(3): 646-658.

Gibson J and McKenzie D (2011) Eight questions about brain drain. Journal of Economic Perspectives 25(3): 107-128.

Hannum H (1987) The Right to Leave and Return in International Law and Practice. New York: Springer Publishing.

Huemer M (2010) Is there a right to immigrate? Social Theory and Practice 36(3): 429-461.

Kennan J (2013) Open borders. Review of Economic Dynamics 16: L1-L13.

Koch W (2006) US urged to apologize for 1930s deportations. USA Today, 5 May. Available at: http://usatoday30.usatoday.com/news/nation/2006-04-04-1930s-deporteescover_x.htm?csp=15 (accessed 24 June 2014). [AQ8]

Lægaard S (2013) Territorial rights, political association, and immigration. Journal of Moral Philosophy 10(5): 645-670.

Macedo S (2008) The moral dilemma of US immigration policy. In: Swaine C (ed.) Debating Immigration. New York: Cambridge University Press, pp. 63-81.

Miller D (2005) Immigration: The case for limits. In: Cohen A and Wellman C (eds) Contemporary Debates in Applied Ethics. Malden, MA: Blackwell Publishing, pp. 193-206.

Miller D (2007) National Responsibility and Global Justice. New York: Oxford University Press.

Miller D (2012) Territorial rights: Concept and justification. Political Studies 60(2): 252-268.

Pevnick R (2011) Immigration and the Constraints of Justice. New York: Cambridge University Press.

Rawls J (2005) Political Liberalism. New York: Columbia University Press.

United Nations Human Development Programme (UNHDP) (2009) Overcoming Barriers: Human Mobility and Development. New York: Palgrave Macmillan.

Walzer M (1983) Spheres of Justice. New York: Basic Books.

Wellman C (2008) Immigration and freedom of association. Ethics 119(1): 109-141.

\section{Author biography}


Javier Hidalgo is an assistant professor at the University of Richmond's Jepson School of Leadership Studies. He received his PhD from the Program in Political Philosophy at Princeton University in 2011. Javier is currently working on the ethics of immigration. 